\title{
SINUS RHYTHM MAINTENANCE AFTER ELECTRICAL CARDIOVERSION FOR ATRIAL FIBRILLATION IN HIGH-RISK PATIENTS - COMPARATIVE EFFICACY OF ANTIARRHYTHMIC MEDICATIONS
}

\author{
Baiba Kokina ${ }^{1, \#}$, Aldis Strēlnieks ${ }^{2,5}$, Irina Pupkeviča ${ }^{2,4}$, Kristīne Jubele ${ }^{2,4}$, \\ Maija Vikmane 2,4 , Sandis Sakne ${ }^{4}$, Emma Sokolova ${ }^{2,4}$, Inga Urtāne ${ }^{3}$, \\ Aivars Lejnieks ${ }^{2,5}$, and Oskars Kalējs ${ }^{2,4}$

\footnotetext{
${ }^{1}$ Faculty of Medicine, Rīga Stradinš̌ University, 16 Dzirciema Str., Rīga, LV-1007, LATVIA

2 Department of Internal Diseases, Rīga Stradinš̌ University, 16 Dzirciema Str., Rīga, LV-1007, LATVIA

${ }^{3}$ Department of Pharmaceutical Chemistry, Rīga Stradinš University, 16 Dzirciema Str., Rīga, LV-1007, LATVIA

${ }^{4}$ Latvian Centre of Cardiology, Pauls Stradiṇš Clinical University Hospital, 13 Pilsoṇu Str., Rĩga, LV-1012, LATVIA

${ }^{5}$ Rīga East University Hospital, 2 Hipokrāta Str., Rīga, LV-1038, LATVIA

\# Corresponding author: bkokina@inbox.lv
}

Contributed by Aivars Lejnieks

\begin{abstract}
Atrial fibrillation (AF) conversion to sinus rhythm by electrical cardioversion (ECV) is followed by the challenge of preventing arrhythmia recurrence, especially in high-risk patients. The properties of class IC, class III and also class II antiarrhythmic medications have been established, but not all effects have been studied. The aim of the study was to compare efficacy of class IC and class III antiarrhythmic medications, and additionally medication with a class II mechanism of action, or taken concomitantly with a beta-blocker, for post-cardioversion sinus rhythm maintenance in patients with high-risk AF. A total of 112 patients who underwent successful ECV in Latvian Centre of Cardiology were included. Data was acquired by a face-to-face interview and 1-, 3-, 6-month follow-up interviews. Comparing class IC (used by 34.8\%) and class III (used by 65.2\%) drugs, there was no statistically significant difference between six-month sinus rhythm maintenance rates $(53.8 \%$ vs. $63.0 \%, p=0.346)$ and arrhythmia-free survival $(\mathrm{p}=0.313)$. Comparing amiodarone (used by $57.1 \%$ ) and ethacizine, concurrently with a beta-blocker (used by $25.9 \%$ ), no statistically significant difference was found between six-month sinus rhythm maintenance $164.1 \%$ vs. $58.6 \%, p=0.616)$ and arrhythmia-free survival $(\mathrm{p}=0.706)$. The results showed that specific antiarrhythmic drug choice was not associated with superior effectiveness, highlighting that, if not contraindicated, ethacizine, concomitantly with a beta-blocker, could be used as a similarly effective alternative for amiodarone, which has adverse health effects.
\end{abstract}

Key words: rhythm control, atrial fibrillation recurrence, antiarrhythmic drugs, amiodarone, ethacizine.

\section{INTRODUCTION}

Atrial fibrillation (AF), the most frequent arrhythmia, is a health problem that is becoming a progressively greater burden (Chugh et al., 2014). Although the preferred treatment strategy still remains, and to some extent is still under debate (Zimetbaum, 2017), rhythm control (restoration and maintenance of sinus rhythm) is an essential part of $\mathrm{AF}$ management, potentially providing clinically relevant bene- fits, especially for symptomatic individuals (Piccini and Fauchier, 2016). Electrical cardioversion (ECV) is regarded as a quick and effective option for AF conversion to sinus rhythm (Kirchhof et al., 2016). Successful sinus rhythm restoration in more than $85 \%$ of cases (Klein and Trappe, 2015 ) is then followed by a less optimistic sinus rhythm maintenance result (Ecker et al., 2018). AF relapse prevention is commonly maintained via antiarrhythmic drug therapy (Lip et al., 2016), promoting more favourable outcomes 
in the post-cardioversion period (Lafuente-Lafuente et al., 2015; Pokorney et al., 2017). In this context, antiarrhythmic medications with class IC and class III properties are usually emphasised, taking into account their proven efficacy, clinical applicability, and longer arrhythmia-free period (Barekatain et al., 2012; Singla et al., 2012). Class II antiarrhythmic properties, corresponding to beta-blocking activity, also play a certain role in maintaining sinus rhythm (Dorian and Angaran, 2014; Lafuente-Lafuente et al., 2015; Grandi and Ripplinger, 2019). There is a fairly extensive range of antiarrhythmic drugs to choose from, with both potential risks and benefits (Sardar et al., 2016; Waks and Zimetbaum, 2017), and the relative efficacies of antiarrhythmic medications still need to be fully studied (Gwag et al., 2018). It is important to emphasise that there is a relative lack of data concerning comparative effectiveness of antiarrhythmic drug classes and specific medications, and not all answers have been obtained with regard to this topic. In addition, it is not only the use of antiarrhythmic medications that has an impact on sinus rhythm maintenance. For instance, it has been established that $\mathrm{CHA}_{2} \mathrm{DS}_{2}$-VASc score values of at least 2 are predictive of early AF recurrence after ECV (Falsetti et al., 2014; Vitali et al., 2019), suggesting that AF recurrence prevention in high-risk patients is more challenging.

The aim of this study was to compare the efficacy of class IC and class III antiarrhythmic medications, and additionally with medication possessing a class II mechanism of action or taken concomitantly with a beta-blocker, for sinus rhythm maintenance after ECV in patients with high-risk AF.

\section{MATERIALS AND METHODS}

This prospective study included patients undergoing ECV for AF in the Latvian Centre of Cardiology, Pauls Stradiňš Clinical University Hospital from October 2018 to June 2019. Specific inclusion criteria for study participants were:

- age at least 18 years;

- non-valvular AF, as specified in the 2016 ESC Guidelines (Kirchhof et al., 2016);

- high-risk $\mathrm{AF}$, defined by $\mathrm{CHA}_{2} \mathrm{DS}_{2}-\mathrm{VASc}$ score 2 or higher for men and 3 or higher for women, according to the 2016 ESC Guidelines (Kirchhof et al., 2016), for included patients to be in more equivalent positions, adapting a factor predictive of being more susceptible to AF recurrence (Falsetti et al., 2014; Vitali et al., 2019) corresponding to the guidelines;

- successful sinus rhythm restoration by ECV;

- prescription of an antiarrhythmic drug with class IC or class III properties;

- prescribed antiarrhythmic medication additionally possessing a class II mechanism of action, or concomitant prescription of a beta-blocker.
All included patients agreed to participate in the study, confirmed by signing a written informed consent. A face-toface interview was conducted and data concerning demographics, medical history, including data available from previous investigations, and medication intake was acquired, according to a data collection protocol. Later, 1-, 3- and 6-month follow-up interviews were conducted with the patients, focusing on intake of antiarrhythmic drugs, with great emphasis on patient compliance and medication persistence, and sinus rhythm maintenance, expressed as full weeks with no AF episodes, the maximum being 26 weeks in this study. A recurrence of AF was defined as the first experienced episode of arrhythmia after the cardioversion procedure, not analysing subsequent changes in cardiac rhythm status. Rhythm control assessment during the follow-up period was based on symptom evaluation, regular doctor visit and health examination results, available investigation reports, including electrocardiographic and, if performed, Holter monitoring data. Further analysis was performed on data related to patients being adherent to antiarrhythmic drug therapy within six months of the ECV procedure at the time of enrolment, or at least, until AF recurrence. Data evaluation and statistical analysis was carried out with Microsoft Excel and IBM SPSS Statistics software, choosing methods appropriate for processing the specific data and defining a significance level $\alpha$ of 0.05 (CL 95\%).

\section{RESULTS}

The total number of patients included for data analysis was 112. Baseline characteristics of study participants are presented in Table 1.

Overall, the 1-month sinus rhythm maintenance rate was $75.9 \%(\mathrm{n}=85)$, followed by a slight reduction, with maintenance of sinus rhythm observed in $66.1 \%(\mathrm{n}=74)$ and $59.8 \%(n=67)$ of patients at 3- and 6-month follow-up, respectively (Fig. 1).

Data regarding sinus rhythm maintenance among all patients was not normally distributed (Kolmogorov-Smirnov test, $\mathrm{Z}=0.368, p<0.001$ ), with a median value of 26 (IQR 4-26) weeks.

Data on antiarrhythmic medication use is summarised in Table 2.

Baseline patient characteristics among class IC and class III antiarrhythmic drug users with the corresponding comparison of included parameters is summarised in Table 3. Evaluating patient subgroups, no statistical significance was established regarding demographics, patient comorbidities and AF characteristics.

In the group of class IC medication users, reported sinus rhythm maintenance rates were $74.3 \%(\mathrm{n}=29)$ at 1 -month follow-up, and $61.5 \%(\mathrm{n}=24)$ and $53.8 \%(\mathrm{n}=21)$ at 3 - and 6-month follow-up interviews, respectively. For class III antiarrhythmic drug users, sinus rhythm maintenance was $76.7 \%(\mathrm{n}=56)$ after 1 month, 68.5\% $(\mathrm{n}=50)$ after three 
Table 1. Baseline characteristics of study participants

\begin{tabular}{|c|c|c|}
\hline \multirow[t]{2}{*}{ Sex } & Men, \% (n) & $58.0(\mathrm{n}=65)$ \\
\hline & Women, \% (n) & $42.0(n=47)$ \\
\hline \multicolumn{2}{|c|}{ Mean age, years (SD) } & $65.5(\mathrm{SD} 9.4)$ \\
\hline \multicolumn{2}{|c|}{ Mean body mass index, $\mathrm{kg} / \mathrm{m}^{2}(\mathrm{SD})$} & $31.5(\mathrm{SD} 6.4)$ \\
\hline \multirow[t]{2}{*}{$\mathrm{CHA}_{2} \mathrm{DS}_{2}$-VASc score } & $\begin{array}{l}\text { Median among men } \\
\text { (IQR Q1-Q3) }\end{array}$ & 3.0 (IQR 2.0-4.0) \\
\hline & $\begin{array}{l}\text { Median among women } \\
\text { (IQR Q1-Q3) }\end{array}$ & 4.0 (IQR 3.0-5.0) \\
\hline \multicolumn{2}{|c|}{ Coronary artery disease, $\%$ (n) } & $39.3(n=44)$ \\
\hline \multicolumn{2}{|c|}{ Myocardial infarction, \% (n) } & $10.7(n=12)$ \\
\hline \multicolumn{2}{|c|}{ Percutaneous coronary intervention, \% (n) } & $13.4(n=15)$ \\
\hline \multicolumn{2}{|c|}{ Arterial hypertension, \% (n) } & $92.9(n=104)$ \\
\hline \multicolumn{2}{|c|}{ Chronic heart failure, $\%(\mathrm{n})$} & $68.8(\mathrm{n}=77)$ \\
\hline \multicolumn{2}{|c|}{ Diabetes, \% (n) } & $18.8(n=21)$ \\
\hline \multicolumn{2}{|c|}{$\begin{array}{l}\text { Mean glomerular filtration rate, } \mathrm{ml} / \mathrm{min} / 1.73 \mathrm{~m}^{2} \\
(\text { SD) }\end{array}$} & $90.9(\mathrm{SD} 31.0)$ \\
\hline \multicolumn{2}{|c|}{ Mean left atrial volume index, $\mathrm{ml} / \mathrm{m}^{2}(\mathrm{SD})$} & $39.0($ SD 7.7) \\
\hline \multirow{2}{*}{$\begin{array}{l}\text { Left ventricular mass } \\
\text { index, } \mathrm{g} / \mathrm{m}^{2}\end{array}$} & Mean among men (SD) & $106.7($ SD 21.5) \\
\hline & $\begin{array}{l}\text { Mean among women } \\
(\mathrm{SD})\end{array}$ & $81.6(\mathrm{SD} 34.3)$ \\
\hline \multicolumn{2}{|c|}{ Mean ejection fraction, $\%(\mathrm{SD})$} & $56.0(\mathrm{SD} 9.4)$ \\
\hline \multirow[t]{3}{*}{ Type of AF } & Paroxysmal, \% (n) & $8.9(n=10)$ \\
\hline & Persistent, \% (n) & $84.8(n=95)$ \\
\hline & $\begin{array}{l}\text { Longstanding persistent, } \\
\qquad \%(\mathrm{n})\end{array}$ & $6.3(\mathrm{n}=7)$ \\
\hline \multicolumn{2}{|c|}{$\begin{array}{l}\text { Median AF episode duration till ECV, weeks } \\
\text { (IQR Q1-Q3) }\end{array}$} & $8.0(4.0-17.0)$ \\
\hline \multicolumn{2}{|c|}{ Median AF history, months (IQR Q1-Q3) } & $16.5(2.3-48.0)$ \\
\hline
\end{tabular}

Quantitative normally distributed data (Kolmogorov-Smirnov test) are presented as mean ( $\mathrm{SD}$, standard deviation), non-normally distributed data and categorical ordinal values are presented as median (IQR, interquartile range Q1, first quartile - Q3, third quartile), categorical nominal values are presented with $\%$, frequencies (n, number of patients)

months and $63.0 \%(n=46)$ after six months. Comparing sinus rhythm maintenance rates for both class IC and class III antiarrhythmic drug groups, no statistically significant differences were established at 1-month (Pearson Chi-Square test, ${ }^{2}=0.077, p=0.781$ ), 3-month (Pearson Chi-Square test, $\left.{ }^{2}=0.548, p=0.459\right)$ and 6 -month (Pearson

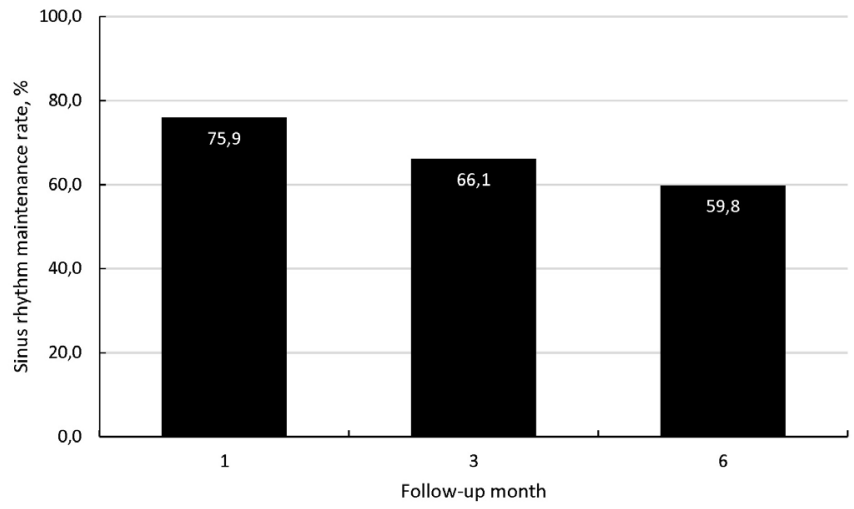

Fig. 1. Sinus rhythm maintenance rates, corresponding to follow-up months.

Chi-Square test, ${ }^{2}=0.889, p=0.346$ ) follow-up. Comparison of sinus rhythm maintenance rates in both groups of patients is shown in Figure 2.

Sinus rhythm duration data were non-parametric for both class IC (Shapiro-Wilk test, $\mathrm{Z}=0.678, p<0.001$ ) and class III (Kolmogorov-Smirnov test, $\mathrm{Z}=0.388, p<0.001$ ) medications, with a median of 26 (IQR 2-26) weeks in the class IC group and 26 (IQR 7-26) weeks for class III users.

The arrhythmia-free survival in class IC and class III antiarrhythmic drug groups, based on sinus rhythm maintenance expressed in weeks until AF recurrence, shown in the form of a Kaplan-Meier curve in Figure 3, did not statistically significantly differ (Breslow test, ${ }^{2}=1.017, p=0.313$ ).

Taking into consideration the number of patients in the antiarrhythmic drug groups, the specific antiarrhythmic medications compared were amiodarone and ethacizine. Characteristics of patients in the amiodarone and ethacizine groups is presented in Table 4. There was no statistical significance between patient-associated factors among participants in both groups.

In the amiodarone group, sinus rhythm maintenance within the first month was reported in $75.0 \%(\mathrm{n}=48)$ cases, and in $68.8 \%(\mathrm{n}=44)$ and $64.1 \%(\mathrm{n}=41)$ at the time of 3 - and 6-month follow-up, respectively. For ethacizine users, the reported rate of sinus rhythm maintenance was $79.3 \%$ ( $\mathrm{n}=$

Table 2. Use of antiarrhythmic medications among study participants

\begin{tabular}{|c|c|c|c|c|c|}
\hline $\begin{array}{c}\text { Antiarrhythmic } \\
\text { drug class }\end{array}$ & Users, \% (n) & Antiarrhythmic drug & Users, \% (n) & $\begin{array}{c}\text { Additional antiarrhythmic } \\
\text { properties (class) }\end{array}$ & $\begin{array}{c}\text { Concomitant beta-blocker } \\
\text { use, } \%(\mathrm{n})\end{array}$ \\
\hline $\mathrm{IC}$ & $34.8(\mathrm{n}=39)$ & Ethacizine & $25.9(n=29)$ & - & $100.0 *(n=29)$ \\
\hline \multirow[t]{2}{*}{ III } & \multirow[t]{2}{*}{$65.2(\mathrm{n}=73)$} & Amiodarone & $57.1(n=64)$ & IA, II, IV *** & $81.3(\mathrm{n}=52)$ \\
\hline & & Sotalol & $8.0(n=9)$ & II $* * *$ & $33.3(n=3)$ \\
\hline
\end{tabular}

* Required, in accordance with the inclusion criteria, for the presence of class II mechanism of action

** Concurrent use of a beta-blocker was not required for inclusion, as propafenone has also demonstrated a class II mechanism (Barekatain and Razavi, 2012; Stoschitzky et al., 2016), and although the clinical significance of this beta-blocking activity is debatable (Faber and Camm, 1996; Stoschitzky et al., 2017), $90 \%$ of patients were taking a beta-blocker concomitantly 
Table 3. Comparative baseline patient characteristics among class IC and class III antiarrhythmic medication users

\begin{tabular}{|c|c|c|c|c|}
\hline & & Class IC & Class III & $p^{*}$ \\
\hline \multirow[t]{2}{*}{ Sex } & Men, \% (n) & $46.2(n=18)$ & $64.4(n=47)$ & \multirow[t]{2}{*}{0.063} \\
\hline & Women, \% (n) & $53.8(\mathrm{n}=21)$ & $35.6(n=26)$ & \\
\hline \multicolumn{2}{|c|}{ Mean age, years (SD) } & $65.7(\mathrm{SD} 8.5)$ & $65.4(\mathrm{SD} 9.9)$ & 0.887 \\
\hline \multicolumn{2}{|c|}{ Mean body mass index, $\mathrm{kg} / \mathrm{m}^{2}(\mathrm{SD})$} & $31.5(\mathrm{SD} 5.4)$ & $30.5(\mathrm{SD} 4.1)$ & 0.843 \\
\hline \multirow[t]{2}{*}{$\mathrm{CHA}_{2} \mathrm{DS}_{2}$-VASc score } & Median among men (IQR Q1-Q3) & $3.0(2.0-4.0)$ & $2.0(2.0-4.0)$ & 0.975 \\
\hline & Median among women (IQR Q1-Q3) & $4.0(3.3-4.8)$ & $3.0(3.0-4.0)$ & 0.354 \\
\hline \multicolumn{2}{|c|}{ Coronary artery disease, $\%$ (n) } & $43.6(n=17)$ & $37.0(n=27)$ & 0.495 \\
\hline \multicolumn{2}{|c|}{ Myocardial infarction, \% (n) } & $10.3(n=4)$ & $11.0(\mathrm{n}=8)$ & 0.909 \\
\hline \multicolumn{2}{|c|}{ Percutaneous coronary intervention, \% (n) } & $10.3(n=4)$ & $15.1(\mathrm{n}=11)$ & 0.476 \\
\hline \multicolumn{2}{|c|}{ Arterial hypertension, \% (n) } & $94.9(n=37)$ & $91.8(n=67)$ & 0.545 \\
\hline \multicolumn{2}{|c|}{ Chronic heart failure, $\%(\mathrm{n})$} & $66.7(n=26)$ & $69.9(n=51)$ & 0.728 \\
\hline \multicolumn{2}{|c|}{ Diabetes, \% (n) } & $10.3(n=4)$ & $23.3(n=17)$ & 0.092 \\
\hline \multicolumn{2}{|c|}{ Mean glomerular filtration rate, $\mathrm{ml} / \mathrm{min} / 1.73 \mathrm{~m}^{2}(\mathrm{SD})$} & $83.6(\mathrm{SD} 25.0)$ & $99.5(\mathrm{SD} 33.5)$ & 0.208 \\
\hline \multicolumn{2}{|c|}{ Mean left atrial volume index, $\mathrm{ml} / \mathrm{m}^{2}(\mathrm{SD})$} & $39.0(\mathrm{SD} 6.6)$ & $40.1(\mathrm{SD} 8.4)$ & 0.268 \\
\hline \multirow{2}{*}{ Left ventricular mass index, $\mathrm{g} / \mathrm{m}^{2}$} & Mean among men (SD) & $99.7(\mathrm{SD} 18.8)$ & $111.6(\mathrm{SD} 22.6)$ & 0.208 \\
\hline & Mean among women (SD) & $89.0(\mathrm{SD} 21.2)$ & $78.7(\mathrm{SD} 38.9)$ & 0.631 \\
\hline \multicolumn{2}{|c|}{ Mean ejection fraction, $\%(\mathrm{SD})$} & $59.1(\mathrm{SD} 2.9)$ & $56.6(\mathrm{SD} 11.7)$ & 0.832 \\
\hline \multirow[t]{3}{*}{ Type of AF } & Paroxysmal, \% (n) & $15.4(n=6)$ & $5.5(n=4)$ & 0.080 \\
\hline & Persistent, \% (n) & $76.9(\mathrm{n}=30)$ & $89.0(\mathrm{n}=65)$ & 0.089 \\
\hline & Longstanding persistent, \% (n) & $7.7(n=3)$ & $5.5(n=4)$ & 0.645 \\
\hline \multicolumn{2}{|c|}{ Median AF episode duration till ECV, weeks (IQR Q1-Q3) } & $8.0(4.0-17.0)$ & $9.0(4.0-17.0)$ & 0.337 \\
\hline \multicolumn{2}{|c|}{ Median AF history, months (IQR Q1-Q3) } & $24.0(2.0-60.0)$ & $16.0(2.5-48.0)$ & 0.542 \\
\hline
\end{tabular}

Quantitative normally distributed data (Kolmogorov-Smirnov test) are presented as means (SD, standard deviation); non-normally distributed data and categorical ordinal values are presented as median (IQR, interquartile range Q1, first quartile - Q3, third quartile), categorical nominal values are presented with $\%$, frequencies (n, number of patients)

* Statistical significance comparing patient characteristics between groups was determined using the Independent-Samples T Test for quantitative normally distributed data (Kolmogrov-Smirnov test) and Mann-Whitney test for non-normally distributed and categorical ordinal data. The Pearson Chi-Square test was used for categorical nominal data.

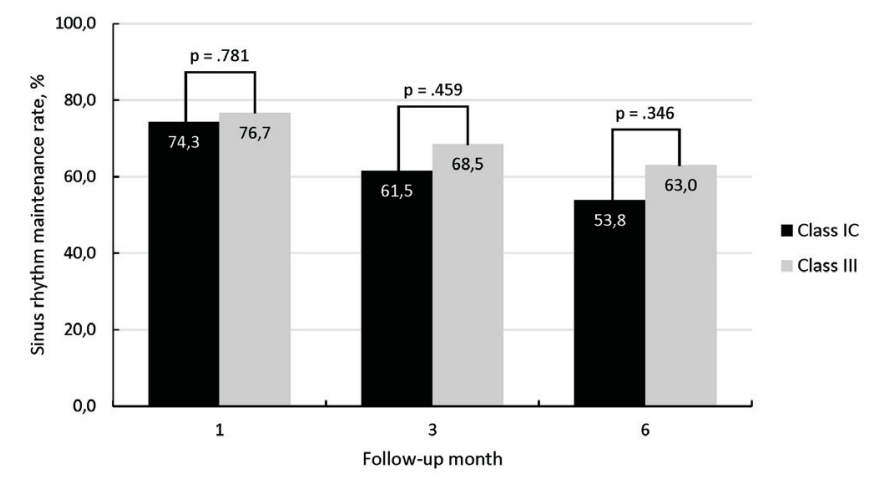

Fig. 2. Sinus rhythm maintenance rates among class IC and class III antiarrhythmic medication users, corresponding to 1-, 3- and 6-month follow-up.

$23)$ at 1 -month follow-up, $65.5 \%(\mathrm{n}=19)$ at 3 -month follow-up and $58.6 \%(\mathrm{n}=17)$ at 6-month follow-up. Comparing rates of sinus rhythm maintenance, no statistically significant differences between these groups were found at 1 -month (Pearson Chi-Square test ${ }^{2}=0.205, p=0.650$ ), 3 -month (Pearson Chi-Square test ${ }^{2}=0.095, p=0.757$ )

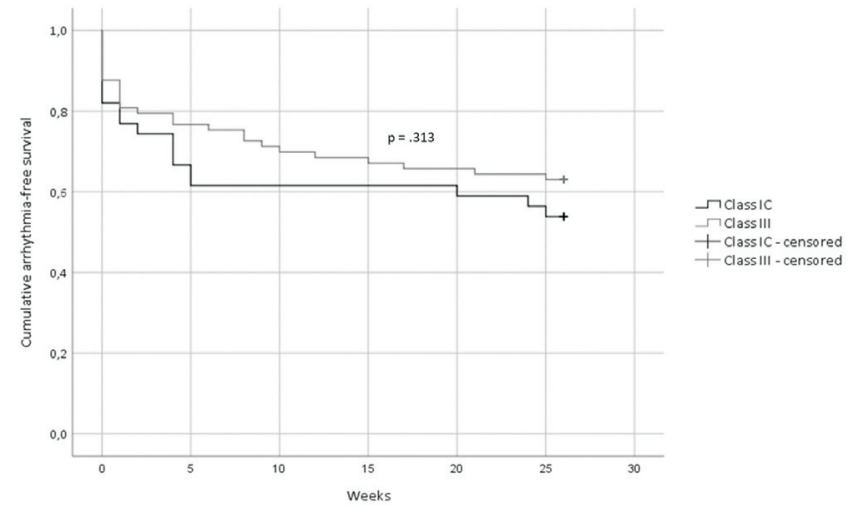

Fig. 3. Arrhythmia-free survival in class IC and class III antiarrhythmic drug groups.

and 6-month (Pearson Chi-Square test ${ }^{2}=0.252, p=$ 0.616) follow-up (Figure 4).

Sinus rhythm maintenance data were not normally distributed in both amiodarone (Kolmogorov-Smirnov test, $\mathrm{Z}=$ $0.395, p<0.001$ ) and ethacizine groups (Shapiro-Wilk test, 
Table 4. Comparative baseline patient characteristics among amiodarone and ethacizine users

\begin{tabular}{|c|c|c|c|c|}
\hline & & Amiodarone & Ethacizine & $p^{*}$ \\
\hline \multirow[t]{2}{*}{ Sex } & Men, \% (n) & $62.5(n=40)$ & $41.4(\mathrm{n}=12)$ & \multirow[t]{2}{*}{0.057} \\
\hline & Women, \% (n) & $37.5(n=24)$ & $58.6(n=17)$ & \\
\hline \multicolumn{2}{|c|}{ Mean age, years (SD) } & $65.6(\mathrm{SD} 9.8)$ & $66.8(\mathrm{SD} 6.7)$ & 0.541 \\
\hline \multicolumn{2}{|c|}{ Mean body mass index, $\mathrm{kg} / \mathrm{m}^{2}(\mathrm{SD})$} & $31.1(\mathrm{SD} 6.7)$ & $31.7(\mathrm{SD} 6.3)$ & 0.692 \\
\hline \multirow{2}{*}{$\mathrm{CHA}_{2} \mathrm{DS}_{2}$-VASc score } & Median among men (IQR Q1-Q3) & $3.0(2.0-4.0)$ & $3.0(2.0-4.0)$ & 0.762 \\
\hline & Median among women (IQR Q1-Q3) & $4.0(3.0-5.0)$ & $4.0(4.0-5.0)$ & 0.464 \\
\hline \multicolumn{2}{|c|}{ Coronary artery disease, $\%(\mathrm{n})$} & $37.5(n=24)$ & $44.8(n=13)$ & 0.504 \\
\hline \multicolumn{2}{|c|}{ Myocardial infarction, \% (n) } & $10.9(\mathrm{n}=7)$ & $10.3(\mathrm{n}=3)$ & 0.932 \\
\hline \multicolumn{2}{|c|}{ Percutaneous coronary intervention, \% (n) } & $15.6(n=10)$ & $10.3(\mathrm{n}=3)$ & 0.496 \\
\hline \multicolumn{2}{|c|}{ Arterial hypertension, \% (n) } & $92.2(n=59)$ & $93.1(n=27)$ & 0.877 \\
\hline \multicolumn{2}{|c|}{ Diabetes, \% (n) } & $23.4(\mathrm{n}=15)$ & $6.9(n=2)$ & 0.056 \\
\hline \multicolumn{2}{|c|}{ Mean glomerular filtration rate, $\mathrm{ml} / \mathrm{min} / 1.73 \mathrm{~m}^{2}(\mathrm{SD})$} & $97.0(\mathrm{SD} 37.8)$ & $82.5(\mathrm{SD} 23.4)$ & 0.222 \\
\hline \multicolumn{2}{|c|}{ Mean left atrial volume index, $\mathrm{ml} / \mathrm{m}^{2}(\mathrm{SD})$} & $40.1(\mathrm{SD} 8.7)$ & $38.2(\mathrm{SD} 6.6)$ & 0.446 \\
\hline \multirow{2}{*}{ Left ventricular mass index, $\mathrm{g} / \mathrm{m}^{2}$} & Mean among men (SD) & $112.6(\mathrm{SD} 23.3)$ & $107.5(\mathrm{SD} 17.5)$ & 0.645 \\
\hline & Mean among women (SD) & $78.7(\mathrm{SD} 38.9)$ & $89.0($ SD 21.2$)$ & 0.631 \\
\hline \multicolumn{2}{|c|}{ Mean ejection fraction, $\%(\mathrm{SD})$} & $56.0(\mathrm{SD} 10.6)$ & $57.1(\mathrm{SD} 4.6)$ & 0.695 \\
\hline \multirow[t]{3}{*}{ Type of AF } & Paroxysmal, \% (n) & $4.7(n=3)$ & $13.8(n=4)$ & 0.052 \\
\hline & Persistent, \% (n) & $89.1(n=57)$ & $75.9(n=22)$ & 0.099 \\
\hline & Longstanding persistent, \% (n) & $6.3(n=4)$ & $10.3(\mathrm{n}=3)$ & 0.488 \\
\hline \multicolumn{2}{|c|}{ Median AF episode duration till ECV, weeks (IQR Q1-Q3) } & $9.5(9.0-17.0)$ & $8.0(2.5-22.0)$ & 0.477 \\
\hline \multicolumn{2}{|c|}{ Median AF history, months (IQR Q1-Q3) } & $15.5(2.0-48.0)$ & $36.0(2.0-54.0)$ & 0.456 \\
\hline
\end{tabular}

Quantitative normally distributed data (Kolmogorov-Smirnov test) are presented as mean (SD, standard deviation), non-normally distributed data and categorical ordinal values are presented as median (IQR, interquartile range Q1, first quartile - Q3, third quartile), and categorical nominal values are presented with $\%$, frequencies ( $n$, number of patients)

* Statistical significance comparing patient characteristics between groups was determined using the Independent-Samples T Test for quantitative normally distributed data (Kolmogorv-Smirnov test), Mann-Whitney test for non-normally distributed and categorical ordinal data, and the Pearson Chi-Square test for categorical nominal data

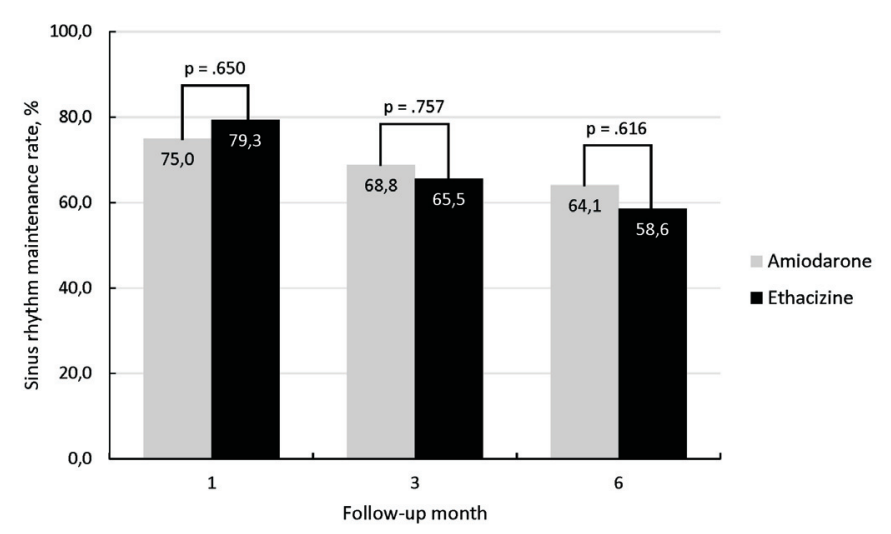

Fig. 4. Sinus rhythm maintenance rates among amiodarone and ethacizine users, corresponding to 1-, 3- and 6-month follow-up.

$\mathrm{Z}=0.665, p<0.001)$. The median sinus rhythm duration was 26 (IQR 4.5-26) weeks in the amiodarone group and 26 (IQR 4-26) weeks among ethacizine users.

Comparing arrhythmia-free survival in amiodarone and ethacizine groups, no statistically significant difference was found (Breslow test, ${ }^{2}=0.143, p=0.706$ ). The survival in these groups is graphically presented as Kaplan-Meier curves in Figure 5.

\section{DISCUSSION}

In this study, evaluation and comparison of the effectiveness of antiarrhythmic medications with class IC and class III properties for sinus rhythm maintenance during a 6month period after AF conversion by ECV was performed in high-risk patients. The potentially enhancing effect of the class II antiarrhythmic mechanism, corresponding to betablocking activity (Lip and Kamath, 2000; Schilling, 2010; Lafuente-Lafuente et al., 2015), was also taken into consideration.

Of the antiarrhythmic medications used by study participants, three are widely known and popular for use in clinical practice worldwide - amiodarone, propafenone and sotalol (Rajagopalan and Curtis, 2012). Extremely limited data is available regarding ethacizine and its efficacy. In 


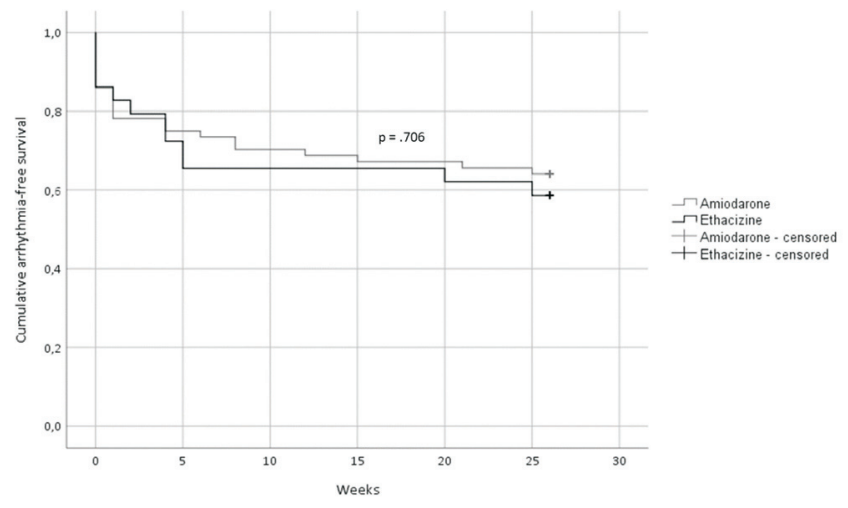

Fig. 5. Arrhythmia-free survival in amiodarone and ethacizine groups.

this study, amiodarone was the most commonly used antiarrhythmic drug, followed by ethacizine, propafenone and sotalol. Thus, drugs with a class III mechanism of action were used more frequently than class IC antiarrhythmic medications. This pattern of use of antiarrhythmic drugs in the involved participants, with amiodarone at the forefront, can be explained by its approved use for patients with conditions such as significant heart disease (Abu-El-Haija and Giudici, 2014; Kirchhof et al., 2016), as in the studied group of high-risk AF patients.

Overall, sinus rhythm maintenance results, with the majority of AF recurrence cases occurring during the first month, are consistent with the information available literature (Martínez-Brotóns et al., 2006; Kirchhof et al., 2012; Vitali et al., 2019).

In this study, no statistically significant difference was found between class IC and class III antiarrhythmic medication groups regarding sinus rhythm maintenance rates, corresponding to follow-up months, as well as arrhythmia-free survival, emphasising that selection of the antiarrhythmic medication class might not be guided by expected superiority. Here, it should be added that the patient risk-profile is essential in decision-making. For instance, underlying significant structural disease is important with regard to the choice of class of antiarrhythmic medication (Dan et al., 2018). Nevertheless, it should be taken into account that, in this study, the inclusion criteria were defined based on for class II activity, and the majority of antiarrhythmic drugs used in the class IC and class III groups were comprised, respectively, by amiodarone and ethacizine.

Amiodarone and ethacizine were compared in terms of sinus rhythm maintenance, these being the two medications most commonly used by patients in this study. It must be emphasised here that all ethacizine users were taking a beta-blocker concomitantly, ensuring more accuracy in the comparison of efficacies, as amiodarone additionally possesses a class II mechanism of action (Roden, 2000). Regarding the evaluation of sinus rhythm maintenance rates, there was no statistically significant difference between these two medications. No statistically significant difference was found for arrhythmia-free survival. Thus, amiodarone did not show any superiority over ethacizine, which could have essential clinical importance. Amiodarone has previously shown greater effectiveness than other antiarrhythmic agents (Schilling, 2010; Saliba and Wazni, 2011) and is considered to be the most effective antiarrhythmic agent for maintenance of sinus rhythm (Gonna and Gallagher, 2014), thereby explaining its widespread use, enhanced by less contraindications, compared to other antiarrhythmic agents (Kirchhof et al., 2016; Dan et al., 2018). Still, prescription of amiodarone is not always reasonable, namely in the absence of heart conditions of enough severity, which would be an indication for amiodarone to be the medication of choice (Qin et al., 2015). Attention needs to be given to the toxicity of amiodarone, and the increasing risk of developing side effects over the course of medication intake (Galperin et al., 2014). Various adverse health effects of amiodarone are known, including thyroid dysfunction (Elnaggar et al., 2018), pulmonary toxicity (Papiris et al., 2010), as well as ocular and skin adverse effects (Park and Kim, 2014). Data obtained in this study indicate that ethacizine, with concurrent use of a beta-blocker and without contraindications, could be used for sinus rhythm maintenance with efficacy comparable to amiodarone. Thereby, adverse health outcomes associated with amiodarone therapy could be avoided minimising potential hazards and improving the risk-benefit profile of the therapy of choice.

The results of this study were obtained for a group of patients meeting the inclusion requirements, such as high-risk AF. It would be of relevant clinical interest to compare outcomes for these medications under divergent study circumstances, which is especially essential for ethacizine, an antiarrhythmic medication having the potential of high effectiveness, but without a sufficient quantity of evidence.

\section{CONCLUSIONS}

In patients with high-risk $\mathrm{AF}$ following $\mathrm{ECV}$, no statistically significant difference was found between efficacy of class IC and class III antiarrhythmic medications (specifically amiodarone and ethacizine) for sinus rhythm maintenance, taking into account class II impact. This indicates that the choice of a specific antiarrhythmic drug is not being associated with superior effectiveness. This highlights that, in the absence of contraindications, ethacizine taken concomitantly with a beta-blocker could be used as a effective alternative for amiodarone, which is associated with adverse health effects.

\section{REFERENCES}

Abu-El-Haija, B., Giudici, M. C. (2014). Predictors of long-term maintenance of normal sinus rhythm after successful electrical cardioversion. Clin. Cardiol., 37 (6), 381-385.

Barekatain, A., Razavi, M. (2012). Antiarrhythmic therapy in atrial fibrillation. Indications, guidelines, and safety. Tex. Heart Inst. J., 39 (4), $532-534$.

Chugh, S. S., Havmoeller, R., Narayanan, K., Singh, D., Rienstra, M., Benjamin, E. J., Gillum, R. F., Kim, Y. H., McAnulty Jr., J. H., Zheng, Z. J., Forouzanfar, M. H., Naghavi, M., Mensah, G. A., Ezzati, M., Murray, C. 
J. L. (2014). Worldwide epidemiology of atrial fibrillation: A global burden of disease 2010 study. Circulation, 129 (8), 837-847.

Dan, G. A., Martinez-Rubio, A., Agewall, S., Boriani, G., Borggrefe, M., Gaita, F., van Gelder, I., Gorenek, B., Kaski, J. C., Kjeldsen, K., et al. (2018). Antiarrhythmic drugs-clinical use and clinical decision making: a consensus document from the European Heart Rhythm Association (EHRA) and European Society of Cardiology (ESC) Working Group on Cardiovascular Pharmacology, endorsed by the Heart Rhythm Society (HRS), Asia-Pacific Heart Rhythm Society (APHRS) and International Society of Cardiovascular Pharmacotherapy (ISCP). Europace, 20 (5), 731-732.

Dorian, P., Angaran, P. (2014). $\beta$-blockers and atrial fibrillation: Hypertension and other medical conditions influencing their use. Can. J. Cardiol., 30 (5 Suppl), S38-41.

Ecker, V., Knoery, C., Rushworth, G., Rudd, I., Ortner, A., Begley, D., Leslie, S. J. (2018). A review of factors associated with maintenance of sinus rhythm after elective electrical cardioversion for atrial fibrillation. Clin. Cardiol., 41 (6), 862-870.

Elnaggar, M. N., Jbeili, K., Nik-Hussin, N., Kozhippally, M., Pappachan, J. M. (2018). Amiodarone-induced thyroid dysfunction: A clinical update. Exp. Clin. Endocrinol. Diabetes, 126 (6), 333-341.

Faber, T. S., Camm, A. J. (1996). The differentiation of propafenone from other class IC agents, focusing on the effect on ventricular response rate attributable to its beta-blocking action. Eur. J. Clin. Pharmacol., 51 (3-4), 199-208.

Falsetti, L., Viticchi, G., Tarquinio, N., Silvestrini, M., Capeci, W., Balloni, A., Catozzo, V., Gentile, A., Pellegrini, F. (2014). $\mathrm{CHA}_{2} \mathrm{DS}_{2}$-VASc in the prediction of early atrial fibrillation relapses after electrical or pharmacological cardioversion. J. Cardiovasc. Med. (Hagerstown), 15 (8), 636-641.

Galperin, J., Elizari, M. V., Bonato, R., Ledesma, R., Vazquez Blanco, M., Lago, M., Spada, P., Sanchez, J., Piasentin, J., Chiale, P. A. (2014). Short-term amiodarone therapy after reversion of persistent atrial fibrillation reduces recurrences at 18 months. Cardiol. J., 21 (4), 397-404.

Gonna, H., Gallagher, M. M. (2014). The efficacy and tolerability of commonly used agents to prevent recurrence of atrial fibrillation after successful cardioversion. Amer. J. Cardiovasc. Drugs, 14 (4), 241-251.

Grandi, E., Ripplinger, C. M. (2019). Antiarrhythmic mechanisms of beta blocker therapy Pharmacol. Res., 146, 104274.

Gwag, H. B., Chun, K. J., Hwang, J. K., Park, S. J., Kim, J. S., Park, K. M., On, Y. K. (2018). Which antiarrhythmic drug to choose after electrical cardioversion: A study on non-valvular atrial fibrillation patients. PLoS One, 13 (5), e0197352.

Kirchhof, P., Andresen, D., Bosch, R., Borggrefe, M., Meinertz, T., Parade, U., Ravens, U., Samol, A., Steinbeck, G., Treszl, A., Wegscheider, K., Breithardt, G. (2012). Short-term versus long-term antiarrhythmic drug treatment after cardioversion of atrial fibrillation (Flec-SL): A prospective, randomised, open-label, blinded endpoint assessment trial. Lancet, 380 (9838), 238-246.

Kirchhof, P., Benussi, S., Kotecha, D., Ahlsson, A., Atar, D., Casadei, B., Castella, M., Diener, H. C., Heidbuchel, H., Hendriks, J., et al. (2016). 2016 ESC Guidelines for the management of atrial fibrillation developed in collaboration with EACTS. Eur. Heart J., 37 (38), 2893-2962.

Klein, H. H., Trappe, H. J. (2015). Cardioversion in non-valvular atrial fibrillation. Dtsch. Arztebl. Int., 112 (50), 856-862.

Lafuente-Lafuente, C., Valembois, L., Bergmann, J. F., Belmin, J. (2015). Antiarrhythmics for maintaining sinus rhythm after cardioversion of atrial fibrillation. Cochrane Database Syst. Rev., 3, CD005049.
Lip, G. Y., Fauchier, L., Freedman, S. B., Van Gelder, I., Natale, A., Gianni, C., Nattel, S., Potpara, T., Rienstra, M., Tse, H. F., Lane, D. A. (2016). Atrial fibrillation. Nat. Rev. Dis. Primers, 2, 16016.

Lip, G. Y. H., Kamath, S. (2000). Atrial fibrillation (2) Antiarrhythmic agents. The Pharm. J., 264 (7094), 659-663.

Martínez-Brotóns, A. M., Ruiz-Granell, R., Morell, S., Plancha, E., Ferrero, A., Roselló, A., Llácer, A., García-Civera, R. (2006). Therapeutic Success of a prospective cardioversion protocol for persistent atrial fibrillation. Rev. Esp. Cardiol., 59 (10), 1038-1046.

Papiris, S. A., Triantafillidou, C., Kolilekas, L., Markoulaki, D., Manali, E. D. (2010). Amiodarone: Review of pulmonary effects and toxicity. Drug Saf., 33 (7), 539-558.

Park, H. S., Kim, Y. N. (2014). Adverse effects of long-term amiodarone therapy. Korean J. Intern. Med., 29 (5), 571-573.

Piccini, J. P., Fauchier, L. (2016). Rhythm control in atrial fibrillation. Lancet, 388 (10046), 829-840.

Pokorney, S. D., Kim, S., Thomas, L., Fonarow, G. C., Kowey, P. R., Gersh, B. J., Mahaffey, K. W., Peterson, E. D., Piccini, J. P. (2017). Cardioversion and subsequent quality of life and natural history of atrial fibrillation. Amer. Heart J., 185, 59-66.

Qin, D., Leef, G., Alam, M.B., Rattan, R., Munir, M. B., Patel, D., Khattak, F., Vaghasia, N., Adelstein, E., Jain, S. K., Saba, S. (2015). Patient outcomes according to adherence to treatment guidelines for rhythm control of atrial fibrillation. J. Amer. Heart Assoc., 4 (4), e001793.

Rajagopalan, B., Curtis, A. B. (2012). Contemporary approach to electrical and pharmacological cardioversion of atrial fibrillation. Postgrad. Med., 124 (6), 26-35.

Roden, D. M. (2000). Antiarrhythmic drugs: from mechanisms to clinical practice. Heart, 84 (3), 339-346.

Saliba, W., Wazni, O. M. (2011). Sinus rhythm restoration and treatment success: Insight from recent clinical trials. Clin. Cardiol., 34 (1), 12-22.

Sardar, M. R., Saeed, W., Kowey, P. R. (2016). Antiarrhythmic drug therapy for atrial fibrillation. Heart Fail. Clin., 12 (2), 205-221.

Schilling, R. J. (2010). Cardioversion of atrial fibrillation: The use of antiarrhythmic drugs. Heart, 96 (5), 333-338.

Singla, S., Karam, P., Deshmukh, A. J., Mehta, J., Paydak, H. (2012). Review of contemporary antiarrhythmic drug therapy for maintenance of sinus rhythm in atrial fibrillation. J. Cardiovasc. Pharmacol. Ther., 17 (1), $12-20$.

Stoschitzky, K., Stoschitzky, G., Lercher, P., Brussee, H. (2017). Oral loading of propafenone: Restoring its role before restoring rhythm-authors' reply. Europace, 19 (11), 1903-1904.

Stoschitzky, K., Stoschitzky, G., Lercher, P., Brussee, H., Lamprecht, G., Lindner, W., 2016. Propafenone shows class Ic and class II antiarrhythmic effects. Europace, 18 (4), 568-571.

Vitali, F., Serenelli, M., Airaksinen, J., Pavasini, R., Tomaszuk-Kazberuk, A., Mlodawska, E., Jaakkola, S., Balla, C., Falsetti, L., Tarquinio, N., Ferrari, R., Squeri, A., Campo, G., Bertini, M. (2019). CHA2DS2-VASc score predicts atrial fibrillation recurrence after cardioversion: Systematic review and individual patient pooled meta-analysis. Clin. Cardiol., 42 (3), $358-364$.

Waks, J. W., Zimetbaum, P. (2017). Drug therapy for rhythm control in atrial fibrillation J. Cardiovasc. Pharmacol. Ther., 22 (1), 3-19.

Zimetbaum, P. (2017). In the clinic: Atrial fibrillation. Ann. Intern. Med., 166 (5), ITC33-ITC48. 
SINUSA RITMA UZTURĒŠANA PĒC ELEKTRISKĀS KARDIOVERSIJAS PACIENTIEM AR AUGSTA RISKA ĀTRIJU FIBRILĀCIJU — ANTIARITMISKO MEDIKAMENTU SALĪDZINOŠĀ EFEKTIVITĀTE

Ātriju fibrilācijas (ĀF) gadījumā sinusa ritma atjaunošanai ar elektrisko kardioversiju (EKV) seko aritmijas atkārtošanās novēršanas izaicinājums, it sevišķi augsta riska pacientiem. Šajā kontekstā pierādīta efektivitāte ir IC klases, III klases un arī II klases antiaritmiskajām īpašībām, tomēr atsevišķi būtiski aspekti joprojām ir aktuāli pētījumiem. Pētījuma mērkis bija salīdzināt IC klases un III klases antiaritmisko medikamentu, kuriem papildus piemīt II klases īpašības vai kuri tika lietoti kopā ar beta blokatoru, efektivitāti pēckardioversijas sinusa ritma uzturēšanai pacientiem ar augsta riska ĀF. Pētījumā tika iekḷauti 112 pacienti, kuriem Latvijas Kardioloğijas centrā veikta veiksmīga EKV. Sākotnējie dati iegūti klātienes intervijā, sekojoši veicot atkārtotas viena, trīs un sešu mēnešu intervijas. Salīdzinot IC klases (34,8\% lietotāju) un III klases antiaritmiskos medikamentus (65,2\% lietotāju), netika iegūta statistiski nozīmīga atšķirība starp sešu mēnešu sinusa ritma uzturēšanas rezultātu $(53,8 \%$ un $63,0 \%, p=0,346)$ un aritmijas-brīvo periodu $(p=0,313)$. Salīdzinot amiodaronu (57,1\% lietotāju) un etacizīnu, kopā ar beta blokatoru (25,9\% lietotāju), netika konstatēta statistiski būtiska atšķirība sešu mēnešu sinusa ritma uzturēšanā $(64,1 \%$ un $58,6 \%, p=0,616)$ un aritmijas-brīvā periodā $(p=0,706)$. Rezultāti norāda uz asociācijas trūkumu starp specifiska antiaritmiska medikamenta izvēli un sagaidāmu augstāku efektivitāti, izceḷot to, ka, pie kontrindikāciju neesamības, etacizīns, kombinācijā ar beta blokatoru, varētu tikt lietots kā vienlīdz efektīva alternatīva amiodaronam, īpaši n,emot vērā tā daudzveidīgo nelabvēlīgo ietekmi uz veselību. 